\title{
Castor in Rome: a god peregrinus in the forum, the collection speaking souls-animae loquentes
}

Keywords: indo-european comparisons, twins, Speaking Souls, hercules, Greek god

\section{Introduction}

In recent times, there has been a renewed interest in the issue of twin-mindedness, in the aspects concerning Rome. It must first of all remember the many works of Alain Meurant, especially its synthesis The idée de gémellité dans la légende des origines de Rome, appeared in Brussels in 2000, where he was studying the various figures of twins in the traditions of the origins of Rome, using to the data of the history of religions and, more particularly, of Indo-European comparisons. Obviously, the most famous twin case for Rome was that of the couple who were at the origin of the city; Romulus et Remus are part of a broader framework of parallel, showing the importance of the twin theme: we can mention that the list is given in an appendix to Volume I of the series The Legend of Rome, From the birth of the twins to the founding of city, edited by A Carandini, due to MT D Alessio, "brothers/twins, between cooperation and conflict", which are distinct "cooperating siblings/twins, "Antagonistic and cooperative-conflict brothers/twin" and finally "antagonistic and cooperative-conflicting brothers/twins who are killed." Another approach is to Véronique Dasen, which seeks to outline how the medicine of antiquity dealt with the phenomenon of gemellità. We may also recall, by Francesca Mencacci, the friend's brothers. The representation of the twins in Roman culture, Venice, 1996, which focuses on historical cases of twins we know. Obviously, there are many ways to address the issue of twins, well beyond their religious importance. Of course, this aspect should not be forgotten and a recent book was published under the title The Twin Gods Horse, The Dioskouroi in Mythologies of the Ancient World, in which the author, Henry John Walker, provides accurate data on the figures of the twins Asvin, the cavalry of India (or Nasatya, that is, "healers") and Dioskouroi in Greece.

The book by Claudia Santi, appeared in the new series of the history of religions Speaking Souls-Animae loquentes, directed by Marcello De Martino, is part of that line. But, inspired by that bibliography, this book, even though it is a divinity that we can call it a twin god, being one of the Dioscuri, has a more limited purpose and in a sense does not speak of twins or twins. It focuses on a single figure of a twin pair, Castor, Pollux's brother in the Dioscuri group and the religious significance he had in Rome. We will return to the question of Castor's twin, or rather that, in Roman worship, it does not look like a part of a twin copy. But we already see the characters of this god in Rome. The subtitle who said it was his nature to Rome: it is "a god peregrinus in the Forum." It did not belong to the old local pantheon, but was inserted at some point in the Uber: the author carefully studied the tradition of the Battle of Lake Regillo, after which he would be introduced to Rome. Tradition recalls in this regard a double prodigy: that, narrated p. es. by Cicero, Dionysius of Alicarnasso and Plutarch, of the intervention in the battle, alongside the Romans, of two mysterious knights, who were identified with the Dioscuri (in the light of the resumption of their intervention alongside the Locresi during the Battle of the Festival at the end of VI century BC, an event
Volume 3 Issue 2 - 2018

\author{
Dominique Briquel \\ Laboratoire d'Archéologie, France \\ Correspondence: Dominique Briquel, Laboratoire \\ d'Archéologie, France, Tel +05 0 I 44 323 I54, Fax +0I 4432 3060, \\ Email dominique.briquel@gmail.com
}

Received: September 03, 2017 | Published: March 21, 2018

already celebrated the mid-fifth century. C. by a sculptural group on the pediment of the ionic temple Marasà) and that, as told by Dionysius but already appeared on a coin of the gens Postumia in 96 BC (and used, perhaps even at that time, to explain the origin of the surname of Ahenobarbus the Domitia gens), the appearance in the court of Rome to two young riders who made watering his horses in Iuturna fountain and announced the victory the citizens still unaware of the outcome of the battle (even the announcement of long-distance military success belongs to the tradition of the Battle of the Festival: Giustino says that the victory of the Locresi it was learned on the same day by Athenians, Corinthians and Spartans). Therefore, clearly borrowed from abroad and molded on the Greek magical pattern, Castor was always recognized as a foreign god, Greek and not Roman. But this was not enough to exclude the national religion: we can think of Hercules, another greek god (and honored according to the greek rite, Graeco ritu), which referred to a well-earlier period and was linked to the very origins of the city. However, Castor's situation was different from that of Caco's winning hero, recognized as god by Evandro on the same ground in Rome. Castor had his temple in the city, within the pomerium and not in a minor place: unlike Hercules, et honored in the commercial port of Rome, away of the official activities of the res publica, Castor was in its center political and religious city, in the heart of the Forum, near a building as important as the 'aedes Vestae, where they kept the fire always have access, fed by the Vestal Virgins, linked to the very existence dell'Urbe: which means that the brother of Pollux was heard, though farfetched of origin, as essential to the res publica Romana. With Castor, godparent god, we certainly have to do with a cult of much more importance to Rome that so many foreign gods, as such, reject you out of the afternoon. Even non-foreign gods, such as those of the Cerere-Liber-Libera plebeian triad, integrated into official worship at the same time, did not enjoy the honor of having their place of worship truly within the city: the Ceremon-Liber-Free Temple, a plebeian counterpart of the official triad of the state that stood on the Capitol, was placed in an extra-peculiar position on the Aventine, with the plebeian and tied to the memory of Remo, not of Romulus.

Really, Castor is not the only exception to a cult of foreign origin: in a recent era Claudia Santi remembers the case of Venus of Mount Eryce in Sicily, whose temple was erected on the Capitol during 
the Second Punic War. But such treatment remains at least unusualespecially if one thinks of the post-pontificate at the same time of the gods of the plebeian triad, of ancient indigenous tradition - and needed a decision taken at the highest state level. Claudia Santi has a certain reason to believe in the news transmitted by Livio about the institution of worship. He also refers to the Battle of Lake Regillo. But the historian dumbfounded the miraculous intervention of the divine knights. The victory was due to the intervention of the Roman cavalry, but this took the form of a tactical process decided by the commander of the Roman army, the dictator Aulus Postumius, a process that appears in other battle stories: the equites dismounted and took part to infantry fighting, acting like a troop of elite infantry, whose intervention proved to be decisive. The action of the men had been joined by the divine: the dictator turned to the divine as all ops' humama ops and made a votum. Perhaps you should not reject the idea that the theme of 'epiphaneia of Castor was born soon, possibly on the same battlefield - to cite one example, not so old, will remember that the unexpected French victory of the Marne, the Marnewunder for Germans, was linked to certain with the appearance of the Virgin Mary on September 8, 1914, a feast of her Nativity: in their view, the Virgin Mary appeared and forbade German soldiers to continue their march towards Paris. But it is obvious that the organization of worship and the erection of the temple in the Forum could not be decided without a procedure like that quoted by Livio. To decide the acceptance of Castor in the Forum, it was necessary to an official decision, such as the completion of a votum decided by a magistrateas the author points out, rightly rejecting the hypothesis of a Evocatio, it would be out of place in a case that was not the siege of an enemy town, or little known and every so unimportant exoratio.

We may be surprised that this cult of undoubtedly Greek origin was immediately welcomed in the center of Rome's political life. But Claudia Santi shows us that if from that time the dioscurian worship had a place in the state religion, it was welcomed in a very different form than what it could have in other environments, even as far away as Etruria or other Latin cities, Lavinium o Tusculum. Particularly worthy of interest is the sharp study she makes of the Dioscuri characters when they appear out of Rome. We dedications in Tarquinia to Tinas cliniiarasi, from the Marsi and Peligni to Iovois puclois or Ioves pucles, that is, to the sons of Jupiter, according to a genealogical perspective was that of Dios Greek Kouroi, but that did not appear in Rome, if not in age more recent and then borrowed from Greek mythology. In Etruria, as shown by Giovanni Colonna (Claudia Santi is right to follow), Dioscuri are psychopomous gods: in the Baron's Tomb they must be recognized in the two knights who accompany the deceased of the family; in that the funeral bed, they are symbolized by the two piloi that are placed in a prominent position, two places pillows on the big bed that occupies the back wall. In Rome, they have no value in the cton, it is infertile. At Tusculum, were honored by lectisternia, then partecipevano to normal religious life of the city, bancheggiando with all its citizens. It is not the case in Rome, where they never appear in the cases we know of this kind of ceremony. All this shows that if the cuto was received in res Roman publica, it was in a particular way: of course Castor was honored by a right in the temple court, but was introduced under a romanized form, which had its place in the official religion and which gave him a different physiotherapy than the one he had elsewhere and did not correspond to the original Greek model.
In Rome, Castore is linked to the cavalry. Of course, this is a very old data, which refer to the inheritance of Indo-European Twin horse gods, which unites the Dioscuroi to Asvin and many other figures and that, in the specific case of Castor, corresponds to a feature which distinguished it from Pollux: already in the 'Odyssey, Castor was defined as a horse trainer, while his brother was a fighter $(11,300)$. This also goes back to the Indo-European origins and finds himself, for India, the epic transposition of Asvin in the Mahabharata, where one is related to the horse, the other an ox. Obviously this stretch explains the preference given to Castore in Rome over his twin. But this aspect becomes absolutely prevalent in the Ulls, to the disappearance of important aspects of the Greeks Dioscuri (which find themselves in Etruria or in other Latin cities). Castor was a saving divinity but his support, requested and received by the Roman dictator, took place in the military environment, not for health or some natural calamity. To use Dumezilian terminology, Indo-European twins were exponents of the third function - recalls that in the ancient tripartite system of the deities of Mitanni, while Varuna and Mitra are the representatives of the first function and Indra the one of the secunda, the Nasatya (that is, the Asvins, counterparts of the Greek Dioscuri) appear for the third function. And in the pantheon of certain Greek cities, we find a tripartite formula similar to that formed by Jupiter, Mars, Quirino in Rome or Odinn, Thor, Freyr in Uppsala. In Rome, it is no longer so.

Indeed, the fact that cavalry twins intervene during a battle is not enough to define them as divinities of secunda function, of military force. We must not fall into the mistake that is often made (e.g in HJ Walker's recent book), that functions are a mere projection of social data and that the first function is the expression of priests, the secunda of warriors, third of peasants or other members of the popular class. Of course, initially Dumézil had conceived his three functions, starting with the organization of Indian or Iranian society. But, as he soon recognized, it is only one of the many applications of an intellectual scheme that tended to divide the whole of the data and not just social ones, in three different perspectives. This explains, for example, that the god of the secunda section in Rome, Mars, appears in the field of agriculture. It is pointless to recapture here the discussed issue of the so-called "Agricultural Mars". The intervention of the god of war is not incompatible with its prevailing military activity: it intervenes with its strength against the dangers that threaten the collection in the same way that it does against the enemies that threaten the city. Its mode of action remains the same; they remain faithful to its functional definition also in areas that are far from the res militaris. The same can be said for twin gods, fundamentally linked to the third function. They can be defined as saving gods; I usually talk about health issues, are related to medicine and therefore in India they wear the name of Nasatya, sanatorias. But they also help other dangers: as they did for the Locres during the Battle of the Festival, they show their resilience even in cases of military crisis, they are about to remedy a situation that might seem desperate. Since the god of the secunda function is not absent from the agrarian world and its activities, even the representatives of the third function and therefore the divine twins that Indo-Europeans relied on this functional level, can assist in war, clashes military. We point out this again, what matters are, in a threefold perspective, not the business sector, but the kind of action.

However, if Dioscours can be defined in relation to the category of third function in the Greek environment, where important figures dating back to the oldest local religious foundation, it would not be appropriate to transfer such an analysis of their value to Roman 
environment. We have to do with them and more precisely with Castor, the only initially introduced as god, his brother remaining in the shadows, with figures appearing secundariamentenel the religious system of the Ubebe, at a time when it is no longer acceptable that antiquity indo-european categories realize the meaning of divine entities. It is enough to remember that since the time of the Etruscan kings, the Jupiter-Marte-Quirino precursor triad was no longer felt as expressing the greatest divine powers to which the city trusted, but was replaced by a very different triad capitoline had its seat on the acropolis of the city and to which the triumphal procession walked, to thank the great pole god, side by side with his two female parrots.

Now, it is obvious that the Dioscuri and Castor, when they were involved in the Roman religion, had no more to see with the concept of "third function," which could still seem operative in Greece for their purpose. They were spoken in the context of a battle, they had behaved then as fighters, also equites to the Roman army and votum decided by the dictator was bound to this manifestation of their rescue skills (which, therefore, he has not carried out during an epidemic, famine or any other occasion that would be a classical crisis manifestation of third function). If it is lawful to resort to the categories of the so-called "Indo-European ideology," this time, it could not resort to the third function, but to the secunda. We have therefore proposed, in an article published a few years ago ("La Bataille du lac Régille et l'origine des temples des Dioscures et de Cérès, et Liber Free", in Liber aureus. Melanges of antiquité et de contemporéanité offerts à Nicole Fick), to see in the intervention of the Greek twins at Lake Regillo the component of secunda function of a series of three dedications to which the young Republic would proceed after the expulsion of the Tarquinii. Three ceremonies of this kind are emphasized in tradition - and only three, although we know that there were other dedications of shrines, such as that of the Temple of Saturn. The first is the dedication of the Temple of Jupiter to the Capitol-a temple whose construction was according to the established tradition and started under the reign of the first of King Tarquinii and was accomplished during the reign of the second, but whose dedication was made only by the new regime Republican. Another dedication is that of CeresLiber-Libera triad: the building it was made by the dictator Aulus Postumius, as part of its military campaign that also sees the votum of the temple of Castor. But it was not related to warlike circumstances, but to problems of troop relief and general famine in the country. If we apply the categories of Indo-European thought to this series of three events that can be considered parallel according to a type of story widely spread throughout the Indo-European world - we are faced with a classic three-function series. The dedication of the temple of the sovereign god, in the heart of the city, made by one of the first magistrates in the city, concerns the first function; that of the temple of the three deities of the agrarian valor, on the outside hill and out of the afternoon of Aventino, socially linked to the plebs and not to the official authorities of the city, concerns the third function; secunda remains for the function of the temple of Castor: the circumstances of his votum are, unlike the others, those of a battle and they act a part of the Roman army, the equites, or, as a judge, not a normal office, but that exceptional, usually decided in the case of military danger, the dictator. The point to point out is that if we accept this analysis, the heirs of Indo-European twins appear here in a context that characterizes them as linked to the second function, not to the third, though, for example, in the list of the gods of the Mitanni they were the divine masters of the third function.
Therefore, Claudia Santi has rightly pointed out the prevailing military character of the Castor god in Rome. His cult (or that of Castor and Pollux) had originally nothing to do with health, important aspect in Greece but only appeared in Rome with the construction of another sanctuary, the one extrapomeriale in circus Flaminio. Another important point from the Greeks, but that could not be for the Romans, the terrestrial people, the protection of navigators did not intervene, at least initially. Instead, the component of the company to which they were bound, as is clear from the circumstances of the temple votum, was military: the body of the equites elite. And the great feast at which the temple of the Forum was connected was the transvectio equitum, that is, the ritual procession of Roman knights, with their weapons, on the day of the Ides of July, the anniversary of the Battle of Lake Regillo and natalis dies of the temple of the Forum, which would have been established, at least for Dionysius of Alicarnasso, already at the time of its inauguration. The iconography of the Dioscuri in Rome emphasized the military character: on numerous coins, they appear as galloping knights, holding their spears, as they had intervened against the Latins. The pileus that is their catteristico headgear was considered by the Romans as a helmet, the pilos that led the Spartans and was never explained, according to the story that he was in Greece, from the legend of the birth of Leda children: the Greeks in fact, they saw in the double twin beret the two halves of the egg in which they would be conceived.

Claudia Santi makes an observation of great interest on the role of Castor - and, primarily Castor - the rituals of the war in Rome, as expressed by the transvectio equitum path and entrusted to this deity a specific place, different than those of the other gods involved in military operations, in the representation of the res militaris. The procession from the temple of Mars to portam Capenam, that is from the outer edge of the city, where he came and where do ritornevano troops. He headed toward the Capitol, the seat of the sovereign god Jupiter, who is also the culmination of triumphalis pump, through which Rome, victorious evidentamente according to the fate of universal domination that the gods had granted him, thanking the god of summo imperium, Jupiter. Castore's place is different. Her temple, occupied a central place on that route each Roman army: it was placed in the heart of the city's political life, where citizens exercised the role of cives, ready to be called as milites for the defense of the city and therefore to become, when it was needed, at the place of raggrupamento legions, outside the pomerium limit, near the temple of Mars to portam Capenam and get the victory that will have given them the supreme god Jupiter, which ringrazierano in his temple Capitolino, when there will be the procession of triumph. But Castore's role in the military life of cities was not only expressed on a topographic plan, according to the course of the cavalry on the July day of July. Each of the three gods involved, Mars, Castor, Jupiter had his own way of dealing with the wars in which Rome was involved. Mars was the master of the technical aspect of the war, the use of the force that arose for the success of the Roman arms, outside the city, against the enemies of the Urbe. Castor, placed on the court, before which paraded annually units of cavalry, the Roman army made up of cives who could become milites if the situation demanded it, in short, to take another divine referencing, the people of the Quirites Quirino ie a Mars tranquillus, able to immediately take up arms. Finally Zeus was the supreme god, guarantor of the sovereignty of Rome and its imperium, which, ultimately gave the victory. If you want, you can do intervene here dumeziliane three functions: it is obvious that it is a 
polarity that responds, first, the structure of political and military life of the res publica Romana.

We have not really addressed the question of twin. We talked about the Dioscuri, their role as saviors in the Greek world, or the homosexual deities we encounter in other areas of the Indo-European world and the fact that they could be considered as related to the third function in this case. But if we focus on Roman data, which is the purpose of Claudia Santi's book, we do not have to do with a twin pair, but with only one god, Castor, the only one to be honored with a temple in the city and enjoy a public worship. Pollux was perhaps, according to legend, appeared with his brother at the Battle of Lake Regillo - as had happened in the festival - but the votum established by the dictator and then the erection of a temple, only looked Castor. We will only postpone to the careful analysis that the author makes of Roman data. In Rome, you have to talk, at least before a later age and a reinterpretation of the Greek name of the temple (which is that, in the Greek version of the Res gestae divi Augusti, the emperor mentions $v \alpha$ ò $\varsigma \tau \tilde{\omega} v \Delta$ toбK ó $\rho \omega v$, while the Latin is mentioned the 'aedes Castoris), not a temple of Castor, but only one member of the twin pair, Castor. Official documents such as Bantia lex, between 133 and $88 \mathrm{BC}$, or Senatus consultum de Tiburtibus, in $56 \mathrm{BC}$, defines the sanctuary as aedes Castoris, concealing the name of Pollux; the same can be seen in the earliest literary evidence: Plautio mentions in all Curculio 'aedes Castoris. The use of the plural Castores, which is sometimes used in the designation of the temple as aedes Castorum, should not be overestimated: the designation does not appear before Pliny the Elder, to be taken in 'Historia Augusta. The temple was therefore the one god, not a couple.

Certainly, there is a difference between the two members of a twin pair and that the couple is unequal, or at least it may be, has been noted for some time. Claudia Santi reminds us of the classical analysis that was the theory of the so-called "dioscurismo," as it was developed by James Rendel Harris (The Dioscuri in the Christian Legends) and Alexandre Hagerty Krappe. According to these authors, for a "primitive" mind, it would be possible for a human being to generate only one son; therefore, if a woman gave birth to two children, one of these could not be generated by her human father, but by a god. So, in that couple, one of the two children was the son of a man, the other of a god and their destiny was different, one being of human and mortal nature, the other of divine and immortal nature. This conception of gemellità as being part of universalia of human thought, had some success and was again followed by Dumezil in the analysis of the most famous twin pair Roman, Romulus and Remo, for the different fate that happened to the sons of Rhea Silvia (though its application is not really acceptable, since the two Roman twins are both sons of the same divine father, the god Mars in the classic form of the legend). But it was subjected to strong criticism in recent times. Claudia Santi shows, quite rightly, very cautious with respect to the idea of "a mythical archetype and meta trasculturale", a "Universal Dioscursim" according to the expression of Donald Ward. It is easy to see that the premise does not correspond to the reality of the data: there are many cases of twins for which no fathers are encountered and the twins can be brought back to a single parent, both divine and human. The universal value of the theory cannot therefore be accepted. But it remains that there are certain cases in which the scheme is applicable and, primarily that of the Dioscuri (although the tradition on the birth of Castor and Pollux is presented, often as in Greece, in various forms, among which would be artificial to draw a rigorous line of chronological evolution). In the case of the sons of Leda, the opposition between a form of God sister, son of Jupiter and one of human nature, the son of Tyndareus, is already attested to the level of the Cypria and it is to think that, as was later pointed out by Pindar, this was already due to the fact that one was the son of god Jupiter, the other of King Tindaro. Each way, one was killed during the clash with the Afretides, Idas and Lynkeus, while the other, immortal, came out without harm - before the beautiful solution of immortality divided alternately between the two brothers granted by Jupiter.

The situation of a fundamental difference between the two Dioscuri, as evidenced by Roman cultural data, is therefore not overwhelming. But if we consider Roman data and refer them to Greek mythology and Greek tradition on the Dioscuri, we are faced with a real absurdity: the one who was honored as a god who had his temple - and in such an important place of city was what was not of divine nature, which was not a god except thanks to the caring intervention of his brother. If we dwell on the logic of the original myth, it would be to wait for the forum's sanctuary to be dedicated to Polluce, not Castore. Of course, the choice of Castor is linked not to consider the myth of Castor and Pollux, such as existed in Greece, but to a historical fact, which refers only to Rome: the circumstances of the introduction of the worship with the votum of Aulus Postumius. This responded to the role of the Roman cavalry at the critical moment of the Battle of Lake Regillo and was therefore consistent with the priority granted to the twin who appeared more tied to the horse. The generic definition given to the Dioscuri as twin horse gods, as it appears in the book of Walker, should not be forgotten that a finer analysis allows distinguishing, in the couple, a more connected to this animal's twin, who is Castor, while the other, Pollux, is characterized in another way (this is the wrestler par excellence). Even in the case of the Indians of Asvian, who also refer to the horse through their name (which is not exclusive, because they are also called Nasatya), one must not neglect the fact that they are, individually, referred to by the horse, but the other to the ox. But it is not the case to dwell on this point, well highlighted by the Dumézil and then taken up by Alain Meurant. Just look, for reprendere an expression du Claudia Santi, that "the bond of Castor with equites appears in Roman religion, as a functional and systemic element". It is therefore normal for the twin of the Romans to be the spezialist of the horses, not his brother.

This demonstrates the fundamental independence of the Roman religion, even when it received new arrivals from abroad. Castor's choice is a real break with the original Greek conception of the Dioscuri. But there is the even more obvious, on which we will consider in the end, the disappearance of gemellità that was an essential feature of the greek Castor and homologous gods in religious representations of the Indo-Europeans. In the story of the battle at Lake Regillo, there were two divine figures to intervene, but in the reality of the sacred topography dell'Urbe and worship, the Romans knew only one God, Castor. Claudia Santi as an elegant solution to this apparent contradiction: in Rome, the idea of twin gods, the amount of other types of kinship, was not acceptable to the gods. The Roman gods were no reports of marital kind, filial or fraternal; therefore, could not exist twin gods. All this belonged to a mythology which was proud not to have left any place in the national religion. Just putting notes on pages where Dionysius of Halicarnassus expressed the contempt in which the Romans kept theirfabulae of the Greeks, for 
them unworthy of the divine majesty. From one point of view, if you can say, theological, the existence of a pair of divine twins bumped Roman thought, the Roman army's rescue during the Battle of Lake Regillo, although perhaps soldiers believed to have seen intervening two knights and then the Romans remained in the city said they saw two similar riders at Iuturna source, was due to a single divine power to a single god. On the strictly religious level, there was only one god, Castor. The gemellità original divine representation was reduced to a single divine entity. For which, as he spoke of the two Pales, the cult was facing only one goddess of that name - or maybe two, but then in an interesting way, Claudia Santi accena to the fact that the same was true probably for the goddess Pales, two different dates, never to two Pales together

It was not the purpose of the author's study of studying the inheritance of the concept of the twin gods Indo-Europeans in Rome, in the truly indigenous religious representations. Remember well the importance of this scheme anywhere in the Indo-European world. The ancient Indians knew the Asvin, the Greeks the Dioscuri. According to Diodoro Siculo, the Celts had similar twin gods of the children of Zeus. Tacitus noted the existence of the couple at Germani of the divine brothers Alcis. And Donald Ward gave a book to the similarity of the Asvin, the Dioscuri and divine beings perceptible in the Baltic legends. But the study of Claudia Santi, even if it concerns a matter of loan, reveals important aspects of the religious mentality of the Romans, not only with respect to external data. The Dioscuri, precisely because they were important deities and why their decisive intervention in the Battle of Lake Regillo deserved to be remembered by the establishment of an official religion and by the erection of a temple at the same hole, could not be accepted as twin gods. However, it is worth remembering that traces of the ancient Indo-European conception of the divine twins and their role related to the third function, you leave probably find in Rome. Really, a type of replication of this legendary prototype, which has often been advanced, there seems to be rejected. The pair of brothers of the founding legend must not, in our view, be related to the type "dioscurico": the uniqueness of his father and a given constant, both the classic version in which they are sons of the god of war and in that primitive, known as Promazione, in which the parent was a male deity god of fire; on the other hand, the existence of the twin pair of Romolo e Remo is limited to the initial part of the life of the founder dell'Urbe and brother appears, so to speak, only to be eliminated when the city is built; Now, in the case of Indo-European twins, they can never cite cases of "twins antagonists who kill", to borrow the terminology MT D'Alessio. It may not return all the twins to a single model, which would be to the god's pair of third Indo-European function. With Romolo e Remo, we have to do with another type of torque, which would be rather that of enemy brothers, according to Abel's model and Cain in the Bible (even if they are not presented as twins, but Alain Meurant has shown that, next to real twins, we also have to do with pairs of brothers who, if they are not identical twins, have a proximity that has the same function mythical), or that of Jacob and Esau, which provides a very exact parallel, as we had the opportunity to suggest in an article of 2013. Instead, the legend of Romulus seems to provide at least the trace of a fraternal couple that we can relate to the archetype of the Indo-European protectors twins. The classic legend Faustolo knew the pastor who welcomed Remus and Romulus after feeding by the wolf. But he had a brother, as evidenced by Dionysius of Halicarnassus and Plutarch, citing it under the name of Plistino o Faustino is to think that these authors have preserved the memory of an element of tradition, of which the presence of Depidii brothers Digidii or in parallel legend of the founder of Praeneste, Caeculo, guarantisce membership in the bottom of the legendary oldest. Now, the couple Faustolo/PlistinoFaustino responds to what we can expect from the twin model of the third Indo-European function as Digidii-Depidii in prenestina legend than Caeculo, Faustolo and his brother than Romolo e Remo a role of shepherds and cattle breeders and protectors who is in the line of twin gods Indo-European who know each other elsewhere. And it is interesting to note that, of Roman coins of Maxentius and Constantine, of which Claudia Santi provides the image, the Dioscuri are depicted next to Romolo e Remo: Is it a late memory of the ancient idea of the protection provided to twins founded legend by a pair of brothers - or at least the references standards to the protective function of twins divine character, thus resurrected the tradition on dell'Urbe origins. But it is not the only case in which we can trace in Rome the old model behind the Greek Dioscuri, Indians Asvin or Dieva deli, sons of the god Heaven Dievs, Baltic folklore. Claudia Santi mentioned the issue of Pales goddesses: in this case, we would be facing a transposition of the male twin gods in a female couple. But there are other cases that deserve to be examined. It is probably not random if, in Pompeian houses or elsewhere, protective deities of the home, the Penates, are figured as a pair. The same is observed at the city level: Dionysius of Halicarnassus has left us a detailed description of how Penates populi Romani in their temple on the Velia: the iconographic model was that of Castor. The same was true for the protectors of the city, the Lares Praestites, who had acanthus them a dog. The relief of the Ara Pacis with Aeneas sees the temple of the Penates of Lavinio even those who were in Rome: there were honored two twin cult figures. Acceniamo only here a subject that deserves to be thorough: the examples cited suffice to show the permanence of the ancient archetype of the twin gods Indo-European in Rome. But it is obvious that we are dealing with elements now come out of the religion of the city proper, surviving in legends - although important, such as the founding of the city - or of divine entities not prominent, like the Penates o Lares. At the level of the great gods of the Roman pantheon, we have the equivalent of Asvin and a tripartite formulation of the pantheon as one of the gods of the Mitanni, in which Nasatya occupying the place assigned in the Roman triad of the dio Quirino, was unthinkable in Rome. As the book of Claudia Santi has well shown, even when the Romans wanted to introduce the worship of the Greek divine twins, they have not allowed the twin depiction. In the couple of Castor, Castor was the only god to whom they have established a cult.

\section{Acknowledgements}

None.

\section{Conflict of interest}

Author declares that there is no conflict of interest. 